\title{
EPIDEMIOLOGICAL ANALYSIS OF BACTERIAL STRAINS INVOLVED IN HOSPITAL INFECTION IN A UNIVERSITY HOSPITAL FROM BRAZIL
}

\author{
Bianca Aguiar DE MORAES(1), Cristiane Andrade Nery CRAVO(1), Marcio Martins LOUREIRO(1), Claude André SOLARI(2) \& Marise Dutra ASENSI(1)
}

\begin{abstract}
SUMMARY
Hospital infections cause an increase in morbidity and mortality of hospitalized patients with significant rise in hospital costs. The aim of this work was an epidemiological analysis of hospital infection cases occurred in a public University Hospital in Rio de Janeiro. Hence, 238 strains were isolated from 14 different clinical materials of 166 patients hospitalized in the period between August 1995 and July 1997. The average age of the patients was 33.4 years, $72.9 \%$ used antimicrobials before having a positive culture. The most common risk conditions were surgery (19.3\%), positive HIV or AIDS (18.1\%) and lung disease (16.9\%). 24 different bacterial species were identified, S. aureus (21\%) and P. aeruginosa (18.5\%) were predominant. Among 50 S. aureus isolated strains $36 \%$ were classified as MRSA (Methicillin Resistant $S$. aureus). The Gram negative bacteria presented high resistance to aminoglycosides and cephalosporins. A diarrhea outbreak, detected in high-risk neonatology ward, was caused by Salmonella serovar Infantis strain, with high antimicrobial resistance and a plasmid of high molecular weight (98Mda) containing virulence genes and positive for $\mathrm{R}$ factor.
\end{abstract}

KEYWORDS: Hospital infection; Antimicrobial resistance; Salmonella outbreak

\section{INTRODUCTION}

Hospital Infections (HI) are a public health problem, mainly, because they increase morbidity and mortality of hospitalized patients, time of hospital stay and costs of treatment (JARVIS, 1987).

In developed countries $\mathrm{HI}$ ranges from 5 to $10 \%$ of hospitalizations (BERGOGNE-BÉRÉZIN, 1995). It is estimated that in the United States from 25,000 to 100,000 deaths are caused directly by HI, with correspondent costs of over 7.5 billion dollars a year (WENZEL, 1994; SMITH \& DOEBBELING, 1996).

Some risk conditions, which are likely to cause HI, have been reported. Some of them are: rise in the number of surgeries, use of catheters, mechanical ventilation, immunosuppressors and new bacterial strains resistant to antimicrobials (AL ORAINEY et al., 1989; SARTOR et al., 1995; KOELEMAN et al., 1997).

The microorganisms related to HI have varied in the last five decades, due to environmental factors and selective pressure of antimicrobial use. Thus, in the 50s the first outbreaks of $S$. aureus resistant to penicillin happened between 1960-1980, S. aureus resistant to oxacillin emerged as well as the Gram negative fermenters, which produce $\beta$-lactamases. After 1980 there were reports of Gram negative non-fermenters, Candida $s p$. and some types of virus (JARVIS, 1987, AL-ORAINEY et al., 1989,
COTTON et al., 1989, BERGOGNE-BÉRÉZIN, 1995; SARTOR et al., 1995, MONNET et al., 1997).

This study reports the frequency of the microorganisms associated with HI in a public University Hospital in Rio de Janeiro, Brazil. It emphasizes the distribution of the microorganisms in several wards, anatomic sites, resistance to antimicrobials and epidemiological data of the patients infected.

\section{MATERIAL AND METHODS}

\section{Description of the Hospital and Population}

Bacterial strains were isolated from patients in different hospital wards of the Hospital Universitário Gafrée \& Guinle (HUGG) Universidade do Rio de Janeiro (UNI-RIO), Brazil. This hospital provides secondary and tertiary assistance to patients of different ages, from several places in Rio de Janeiro City and State. The data collected on each infection included the date, site of infection and patient demographic characteristics.

\section{Bacterial Strains and Susceptibility Testing}

A total of 238 bacteria strains isolated from 14 different anatomic sites (Table 2) were obtained from patients with infection. The criteria

(1) Laboratório de Enterobactérias, Departamento de Bacteriologia, Instituto Oswaldo Cruz, Fundação Oswaldo Cruz, Rio de Janeiro, Brazil.

(2) Hospital Universitário Gaffrée e Guinle, Universidade do Rio de Janeiro, Brazil.

Correspondence to: Dr. M.D. Asensi, Pav. Rocha Lima, $3^{\circ}$ Andar, IOC/Fiocruz, Av. Brasil 4365, 21045-900 Manguinhos, Rio de Janeiro, Brasil. 


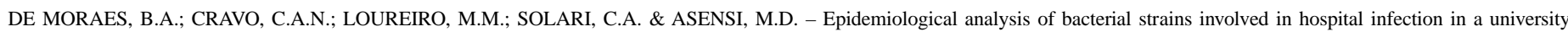
hospital from Brazil. Rev. Inst. Med. trop. S. Paulo, 42(4): 201-207, 2000.

for defining nosocomial infection followed the National Nosocomial Infection Surveillance System (NNISS) according recomendations of Ministry of Health-Brazil, 1994. NNISS defines a nosocomial infection as any infection that is not present or incubating at the time the patient is admitted to the hospital, so was considered $\mathrm{IH}$ as being any infection occurrence after $48 \mathrm{~h}$ of hospitalization. Each patient's record was analysed criteriously, and based on clinical aspects, laboratorial data, type of infection and clinical specimen, the strain was classified as representative of infection or not. Surgical site infection were classified as infection occurrence within 30 days of the operation. Neonates infections were classified as any infection acquired after birth. All ConS strains were reported as the cause of a bloodstream infection only if the patient had fever, chills or hypotension and had no clinical evidence of sepsis at another site. The culture and identification followed the rules of BALOWS et al. (1991). The Gram-negative identification was completed by the Crystal System of identification for fermenters and non-fermenters (BBL/Becton-Dickinson). The antimicrobial susceptibility test was carried out through disk diffusion method in agardisk of CECON, complying with NCCLS (National Committee for Clinical Laboratory Standards) recommendations (1995). Quality control was carried out using standard strains of Escherichia coli (ATCC 25922), P. aeruginosa (ATCC 27953) and S. aureus (ATCC 25923).

\section{Plasmid Profile Analysis}

Plasmid Profile analysis was performed through the alkaline lysis method of BIRNBOIM \& DOLY (1979), modified by SAMBROOK et al. (1989). Samples of $15 \mu 1$ plasmid preparation were loaded into wells with $0.8 \%$ agarose gel of $7.5 \mathrm{~cm}$ length and run at $40 \mathrm{~V}$ for 2 hours on a horizontal electrophoresis apparatus with a constant power source. Gels were stained with ethidium bromide and visualized on an UV transilluminator. Photographs were taken with a Polaroid Type 667 film. The plasmidial DNA of Escherichia coli R861 and V517 (THRELLFALL et al., 1986; MACRINA et al., 1978) were included as molecular controls.

\section{Determination of the presence of $\mathbf{R}$ factors}

Cultures of Salmonella serovar Infantis and of the receptor strains Escherichia coli $\mathrm{K} 12 \mathrm{~F}^{-}, \mathrm{Lac}^{+}$and $\mathrm{Nal}^{\mathrm{r}}$ (originally from the Biophysics Institute, Federal University of Rio de Janeiro) were incubated at 1:10 inoculum proportion at $37{ }^{\circ} \mathrm{C}$ for $18 \mathrm{hr}$. Transconjugants were plated onto Agar McConkey, with the antimicrobial drugs added individually at the following concentrations: ampicillin, $10 \mathrm{mcg} / \mathrm{mL}$ - gentamicin $10 \mathrm{mcg} / \mathrm{mL}$; ceftriaxone $-16 \mathrm{mcg} / \mathrm{mL}$. All plates contained nalidixic acid at the concentration of $30 \mathrm{mcg} / \mathrm{mL}$.

The growth of lactose-positive colonies (transconjugants) indicated the transfer of resistance markers. This result was confirmed by an antimicrobial susceptibility test and plasmid profile analysis of the transconjugants, considering the original pattern of the corresponding donor colony.

\section{Epidemiological analysis of patients}

For each HI case an epidemiological report was done. It contained patients' data. These data were saved in an EXCEL 5.0 program (Microsoft) and analyzed later in Epi-Info Version 6.04b - January-1997.

\section{RESULTS}

According to the epidemiological report, several parameters were analysed. General features of 166 patients studied can be seen in Table 1. The average age was 33.4, and average number of days of hospitalization before the HI was 25.4 days. $72.9 \%$ of the patients used prophylactic or therapeutic antimicrobials before presenting a positive culture. In the case of polimicrobial infections, an average of 2.9 strains per anatomic site was detected. The risk conditions which were mostly related to the HI process were surgery $(19.3 \%)$, HIV infection $(18.1 \%)$, lung disease $(16.9 \%)$ and prematurity $(12.0 \%)$.

A total of 28 different types of antimicrobials (Table 2) were used prior to the positive culture, with a predominance of amikacin $(11.9 \%)$, ampicillin (11.6\%), gentamicin (11.0\%) and ceftriaxone $(10.0 \%)$.

24 different species were identified (Table 3), with higher frequency of $S$. aureus $(21.0 \%)$ followed by $P$. aeruginosa (18.5\%); Coagulasenegative staphylococci $(9.7 \%)$ and $K$. pneumoniae $(8.8 \%)$. The $50 \mathrm{~S}$. aureus strains were mainly distributed in Internal Medicine Wards (IMW) and General Surgery Wards (GSW). 17 (38.6\%) strains of $P$. aeruginosa were from IMW and 9 (20.4\%) from GSW. The other species were uniformely distributed by other wards. We detected an outbreak of Salmonella serovar Infantis in the Neonatology Intensive Care Unity.

Table 1

Epidemiological data of the 166 patients with nosocomial infections caused by 238 agents

\begin{tabular}{lc}
\hline Epidemiological Data & $\begin{array}{c}\text { Total Number of } \\
\text { Patients }-166\end{array}$ \\
\hline Mean Age \pm SD & $33.4 \pm 27.8$ \\
Male & $105(63.3 \%)$ \\
Female & $61(36.7 \%)$ \\
Mean of hospitalization days before HI presentation & $25.4 \pm 27.9$ \\
Number of patients in use of antibiotics before & \\
positive culture & $121(72.9 \%)$ \\
Mean of antibiotic use days before positive culture & 15.9 \\
Mean number of infection /patient & 1.6 \\
Number of polimicrobial infections cases & $37(22.3 \%)$ \\
Mean number of strains /polimicrobial & \\
infections cases (*) & 2.9 \\
Risk conditions of 166 patients & \\
Surgical case & $32(19.3 \%)$ \\
HIV infection & $30(18.1 \%)$ \\
Lung disease & $28(16.9 \%)$ \\
Prematurity & $20(12.0 \%)$ \\
Diabetes & $11(6.6 \%)$ \\
Renal distress & $10(6.0 \%)$ \\
Cancer & $10(6.0 \%)$ \\
Others & $19(11.4 \%)$ \\
Patient data not found & $6(3.6 \%)$ \\
\hline
\end{tabular}

$\mathrm{SD}=$ Standard deviation; $(*)$ - Total of 107 isolated strains 
Table 2

Frequency of antimicrobial use before the positive culture isolation

\begin{tabular}{lcc}
\hline Antimicrobials & Frequency of use* & $\%(\mathrm{~N}=121)$ \\
\hline Amikacin & 38 & 11.9 \\
Ampicillin & 37 & 11.6 \\
Gentamicin & 35 & 11.0 \\
Ceftriaxone & 32 & 10.0 \\
Cephalotin & 25 & 7.8 \\
Oxacillin & 23 & 7.2 \\
Trimethoprim-sulfametoxazole & 21 & 6.6 \\
Ceftazidime & 17 & 5.3 \\
Vancomicin & 16 & 5.0 \\
Cefotaxime & 14 & 4.4 \\
Penicillin & 11 & 3.4 \\
Cefoxitine & 11 & 3.4 \\
Ciprofloxacin & 9 & 2.8 \\
Cephalexin & 4 & 1.2 \\
Clindamicin & 4 & 1.2 \\
Metronidazole & 4 & 1.2 \\
Chloramphenicol & 3 & 0.9 \\
Norfloxacin & 2 & 0.6 \\
Erithromicin & 2 & 0.6 \\
Rifampicin & 2 & 0.6 \\
Imipenem & 1 & 0.3 \\
Tobramicin & 1 & 0.3 \\
Tetracycline & 1 & 0.3 \\
Nitrofurantoin & 1 & 0.3 \\
Cefuroxime & 1 & 0.3 \\
Amoxacillin & 1 & 0.3 \\
Rovamicin & 0.3 \\
Sulfadiazine & 0.3 \\
\hline
\end{tabular}

*- Many patients were treated with more than one drug at the same time.

The number of bacterial strains isolated according to the type of clinical material cultured is shown in Table 4. S. aureus was the predominat bacterium in surgical wound, blood, vascular catheter and cutaneus lesions. $P$. aeruginosa were most frequently isolated in surgical wound abdominal secretions and enteric tract, Coagulase- negative staphylococci (CoNS), K. pneumoniae and A. baumanni were frequently isolated from blood.

Considering the resistance to antimicrobial agents, $36 \%$ of the $S$. aureus were resistant to oxacillin. The resistance of Gram negatives to the antimicrobials is shown in Table 5. We observed a high percentage of resistance to aminoglycosides (gentamicin and amikacin) and $3^{\text {rd }}$ generation of cephalosporins (Ceftriaxone and Ceftazidime). There was a high percentage of $P$. aeruginosa $(59.5 \%)$ resistant to carbenicillin and of $A$. baumanni resistant to ciprofloxacin, in spite of the latter being a controlled antimicrobial. Imipenem was the most active agent against $K$. pneumoniae, the others Enterobacteriaceae (E. coli, E. cloacae, P. vulgaris, M. morganii, $P$. rustigianii and $S$. marcescens) were more resistant.

An outbreak of Salmonella serovar Infantis, occurred between 05/ April -20/April/1996 affected nine hospitalized children in the high risk nursery (Table 6). These were studied in more detail. All of them had severe disease: six had respiratory problems and three had low body weight. The antimicrobial resistance and plasmidial DNA profiles of all the strains were identical, with only one plasmid (98 Mda). In the determination of the presence of $\mathrm{R}$ factors, all of the strains transfered the resistance plasmid to the standard strain recipient $E$. coli $\mathrm{K} 12$.

\section{DISCUSSION}

The HUGG provides assistance to adults, children and neonatology. It is, also, a reference hospital for some diseases such as: acquired immunodeficiency syndrome, diabetes and cancer. In this way, a large part of the patients, due to their underlying diseases are more especially susceptible to acquired hospital infections.

This bacteriological study, complemented with information about patients in hospital, had some aspects. The S. aureus (21\%) was the predominant pathogen (Tables 3, and 4). SADER et al. (1999), in a multicentric study, related similar result in blood and surgical wounds infections.

In Table 1, it is interesting to point out the average number of days of hospitalization ( 25.4 days) before the diagnosis of $\mathrm{HI}$, a long time of hospitalization, as well as, the long time of previous use of antimicrobials (15.9 days). These factors permit the emergence of multirresistant bacteria. MANRIQUE \& GALVÃO (1996), reported that the use of prophylactic or therapeutic antimicrobials, may result in the spread of multirresistant strains in the hospital. Another aspect is that risk conditions or underlying diseases may have favored the occurrence of $\mathrm{HI}$ in some hospital areas, mainly in surgery wards and intensive care units. The Table 3 shows that wards SW, IMW, NICU and PICU sum up $36 \%$ of the places studied, according to SARTOR et al. (1995).

Polimicrobial infection (22.3\% of the cases) represented a challenge in establishing proper treatment and emphasized the importance of obtain cultures for every bacterial infection in hospitalized patients before starting an empiric treatment. DUNCAN et al., (1994), mention that some infections demand empiric antimicrobial therapy; however, this type of therapy should be guided by previous study in vitro susceptibility of the most frequent the HI bacterial strains of higher frequency in the hospitals.

Regarding the frequency of the microorganisms, $S$. aureus and $P$. aeruginosa sum up $39.5 \%$ of the total isolates; Coagulase- negative staphylococci (CoNS), K. pneumoniae, E. coli and A. baumannii sum up $32.4 \%$. The other $28.2 \%$ were represented by other 18 bacterial species. These microorganisms have been described in the literature as the main causes of $\mathrm{HI}$ in hospitals that provide tertiary assistance to HIV patients and high risk newborns (AYLIFFE, 1997; JARVIS, 1987; BERGOGNE-BÉRÉZIN, 1995; SARTOR et al., 1995; MONNET et al., 1997; STROUD et al., 1997; SADER et al., 1999). It is also important to point out that the distribution of microorganisms mostly involved in $\mathrm{HI}$ is directly related to the origin (wards) of the patients and type of clinical material. The knowledge of the hospital indigenous flora isolated from each anatomical sites allows a better choice of empirical treatment.

The level of multirresistance of the species of the KES group (Klebsiella sp., Enterobacter sp. and Serratia sp.) is worrying, since these microorganisms are rather frequent, distributed in several wards of the hospital. The multirresistance in this group is related to the 


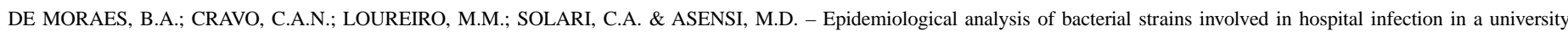
hospital from Brazil. Rev. Inst. Med. trop. S. Paulo, 42(4): 201-207, 2000.

Table 3

Frequency of bacterial strains according the ward

\begin{tabular}{|c|c|c|c|c|c|c|c|}
\hline Microrganism & GSW* & IMW & NICU & $\mathrm{PW}$ & ICU & PICU & Total $(\%)$ \\
\hline Staphylococcus aureus & 12 & 25 & 4 & 1 & 2 & 6 & $50(21.0)$ \\
\hline Staphylococcus coag. neg. & 7 & 3 & 4 & 1 & 1 & 7 & $23(9.7)$ \\
\hline Streptococcus sp. & 3 & 1 & 1 & & 1 & - & $6(2.5)$ \\
\hline Klebsiella pneumoniae & 5 & 4 & 2 & 3 & 2 & 5 & $21(8.8)$ \\
\hline Klebsiella oxytoca & - & - & 1 & - & - & - & $1(0.4)$ \\
\hline Escherichia coli & 12 & 3 & - & - & 1 & 2 & $18(7.6)$ \\
\hline Enterobacter aerogenes & 3 & 1 & - & - & - & 1 & $5(2.1)$ \\
\hline Enterobacter cloacae & 1 & - & 1 & - & 1 & 4 & $7(2.9)$ \\
\hline Enterobacter sakazakii & - & - & - & - & - & 1 & $1(0.4)$ \\
\hline Enterobacter sp. & 1 & - & - & - & - & 1 & $2(0.8)$ \\
\hline Proteus mirabilis & 4 & 2 & - & - & - & 1 & $7(2.9)$ \\
\hline Proteus vulgaris & 2 & - & - & - & 1 & - & $3(1.3)$ \\
\hline Providencia rustigianii & - & - & 1 & - & - & - & $1(0.4)$ \\
\hline Morganella morganii & 5 & 1 & - & - & - & 2 & $8(3.4)$ \\
\hline Serratia marcescens & 1 & 2 & - & - & - & 1 & $4(1.7)$ \\
\hline Citrobacter freundii & 2 & - & - & - & - & - & $2(0.8)$ \\
\hline Pseudomonas aeruginosa & 9 & 17 & 4 & 3 & 7 & 4 & $44(18.5)$ \\
\hline Burkholderia cepacia & - & - & - & - & - & 2 & $2(0.8)$ \\
\hline Pseudomonas putida & - & 1 & - & - & - & - & $1(0.4)$ \\
\hline Stenotrophomonas maltophilia & 1 & 3 & - & - & - & - & $4(1.7)$ \\
\hline Acinetobacter baumannii & 4 & 5 & 3 & - & 1 & 2 & $15(6.3)$ \\
\hline Flavobacterium odoratum & 1 & - & - & - & - & - & $1(0.4)$ \\
\hline Salmonella serovar Infantis & - & - & 9 & - & - & - & $9(3.8)$ \\
\hline Non fermenters Gram negatives & 1 & 1 & - & - & 1 & - & $3(1.3)$ \\
\hline Total & 74 & 69 & 30 & 8 & 18 & 39 & 238 \\
\hline
\end{tabular}

$\mathrm{GSW}^{*}$ = General Surgery Wards; IMW = Internal Medicine Wards; NICU = Neonatology Intensive Care Unity; PW = Pediatric Ward; ICU = Intensive Care Unity; PICU= Pediatric Intensive

Table 4

Number of bacterial strains isolated according to the site of infection

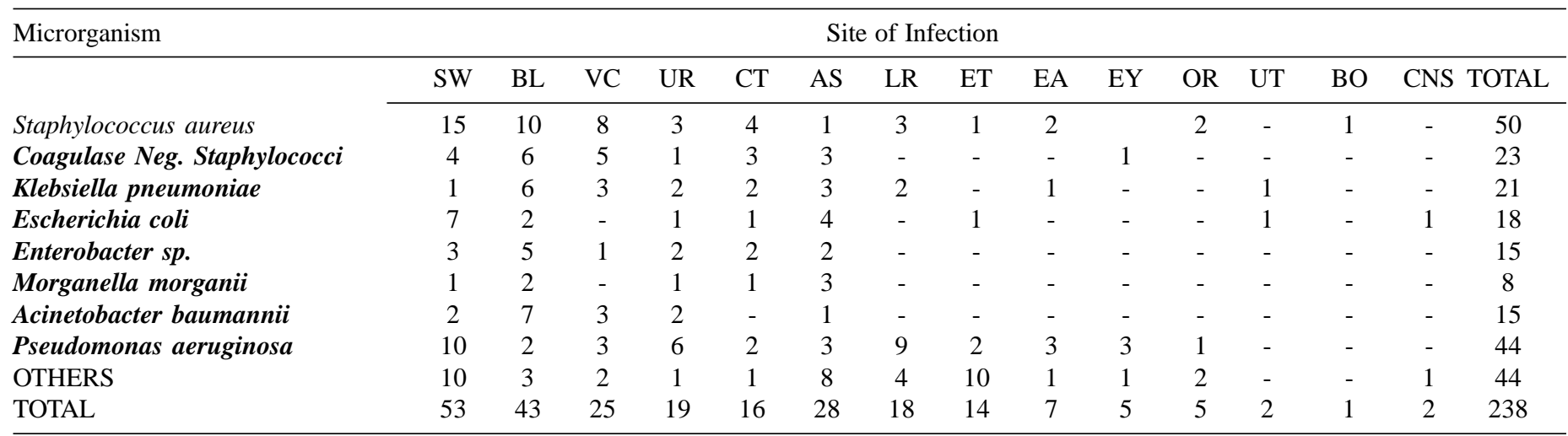

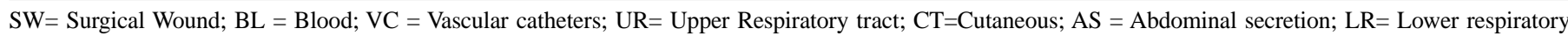
tract; $\mathrm{ET}=$ Enteric tract; $\mathrm{EA}=$ ear; $\mathrm{EY}=$ eye; OR= Oropharingis; $\mathrm{UT}=$ Urinary tract; $\mathrm{BO}=\mathrm{Bone}$; CNS = Central nervous system. 
Table 5

Percentage of resistance to antimicrobial agents in Gram negatives strains

\begin{tabular}{|c|c|c|c|c|c|c|c|c|c|c|c|c|c|c|}
\hline \multirow[t]{2}{*}{ Microrganism } & \multicolumn{14}{|c|}{ Antimicrobial } \\
\hline & AMP & CPL & CFO & CRX & $\mathrm{CRO}$ & CAZ & CAR & IMP & CIP & GEN & AMI & TET & CLO & TSX \\
\hline K. pneumoniae & 100 & 76 & 14 & 76 & 57 & - & - & 0 & 5 & 57 & 57 & 52 & 48 & 52 \\
\hline K. oxytoca & 100 & 100 & 0 & 100 & 100 & - & - & 0 & 0 & 100 & 100 & 0 & 100 & 100 \\
\hline E. coli & 82 & 67 & 11 & 39 & 11 & - & - & 5 & 11 & 11 & 11 & 59 & 39 & 41 \\
\hline E. aerogenes & 100 & 100 & 80 & 80 & 60 & - & - & 0 & 0 & 40 & 20 & 60 & 60 & 60 \\
\hline E. cloacae & 100 & 100 & 100 & 100 & 86 & - & - & 14 & 29 & 86 & 86 & 86 & 100 & 57 \\
\hline E. sakazakii & 100 & 100 & 100 & 100 & 100 & - & - & 0 & 0 & 100 & 100 & 0 & 100 & 100 \\
\hline Enterobacter sp. & 100 & 50 & 100 & 50 & 100 & - & - & 0 & 50 & 100 & 100 & 100 & 0 & 50 \\
\hline P. mirabilis & 33 & 43 & 29 & 57 & 0 & - & - & 15 & 14 & 14 & 0 & 100 & 57 & 57 \\
\hline P. vulgaris & 100 & 33 & 0 & 100 & 0 & - & - & 0 & 0 & 33 & 0 & 33 & 33 & 67 \\
\hline P. rustigianii & 0 & 100 & 0 & 0 & 0 & - & - & 100 & 0 & 0 & 0 & 100 & 0 & 0 \\
\hline M. morganii & 100 & 100 & 50 & 75 & 12 & - & - & 12 & 0 & 0 & 12 & 37 & 11 & 0 \\
\hline S. marcescens & 100 & 100 & 100 & 75 & 0 & - & - & 25 & 0 & 75 & 100 & 75 & 100 & 100 \\
\hline P. aeruginosa & 95 & 95 & 86 & 93 & 85 & 46 & 59 & 5 & 33 & 52 & 40 & 90 & 79 & 90 \\
\hline B. cepacia & 100 & 100 & 100 & 100 & 100 & 100 & 100 & 0 & 0 & 100 & 0 & 100 & 100 & 100 \\
\hline P. putida & 100 & 100 & 100 & 100 & 100 & 100 & 100 & 0 & 100 & 100 & 100 & 0 & 100 & 100 \\
\hline S. maltophilia & 100 & 100 & 100 & 100 & 100 & 0 & 100 & 100 & 25 & 75 & 100 & 100 & 50 & 25 \\
\hline A. baumannii & 93 & 100 & 100 & 87 & 87 & 36 & 64 & 0 & 36 & 57 & 57 & 28 & 100 & 71 \\
\hline F. odoratum & 100 & 100 & 100 & 100 & 0 & 0 & 0 & 0 & 0 & 0 & 0 & 0 & 0 & 0 \\
\hline C. freundii & 100 & 100 & 50 & 100 & 0 & 100 & 0 & 0 & 0 & 0 & 0 & 100 & 100 & 0 \\
\hline$S$. Infantis & 100 & 100 & 0 & 100 & 100 & 100 & 100 & 0 & 0 & 100 & 100 & 100 & 100 & 100 \\
\hline Non fermenter GNB & 100 & 100 & 100 & 67 & 67 & 100 & 100 & 0 & 67 & 67 & 67 & 33 & 67 & 67 \\
\hline Total percentage & 93 & 76 & 55 & 72 & 62 & 56 & 46 & 16 & 30 & 55 & 50 & 62 & 59 & 55 \\
\hline
\end{tabular}

AMP- Ampicillin; CPL- Cephalotin; CFO- Cefoxitin; CRX- Cefuroxime; CRO- Ceftriaxone; CAZ- ceftazidime; CAR- carbenicillin; IMP- Imipenen; CIPCiprofloxacin; GEN- Gentamicin; AMI- Amikacin; TET- Tetracycline; CLO- Chloramphenicol; TSX- trimethoprim -Sulfametoxazole.

Table 6

General clinical-pathological data from newborns with diarrhoea caused by Salmonella serovar Infantis isolated from faeces in 1996

\begin{tabular}{|c|c|c|c|c|c|c|c|}
\hline Patient & $\begin{array}{l}\text { Date of } \\
\text { isolation }\end{array}$ & $\begin{array}{c}\text { Birth } \\
\text { weight }\end{array}$ & $\begin{array}{l}\text { Age } \\
\text { (days) }\end{array}$ & $\begin{array}{l}\text { Rupture of } \\
\text { membranes }\end{array}$ & Prematurity & $\begin{array}{l}\text { Type of } \\
\text { partum }\end{array}$ & $\begin{array}{c}\text { Cause of } \\
\text { Admission }\end{array}$ \\
\hline GG 1 & $05 / 07$ & $1465 \mathrm{~g}$ & 6 & $>24$ hours & yes & Normal & RDS \\
\hline GG 2 & $05 / 13$ & $1105 \mathrm{~g}$ & 37 & $<24$ hours & yes & Cesarean & RDS \\
\hline GG 3 & 05/07 & $2990 \mathrm{~g}$ & 63 & $<24$ hours & no & Normal & Asphyxia \\
\hline GG 4 & $05 / 07$ & $3470 \mathrm{~g}$ & 8 & - & no & Cesarean & Tachypneic \\
\hline GG 5 & 05/07 & $3170 \mathrm{~g}$ & 14 & - & no & Cesarean & Gastric enteritis \\
\hline GG 6 & $05 / 07$ & - & 7 & - & no & Normal & Jaundice + skin infection \\
\hline GG 7 & $05 / 13$ & $2810 \mathrm{~g}$ & 7 & $<24$ hours & yes & Normal & RDS \\
\hline GG 8* & $05 / 14$ & - & - & - & - & - & - \\
\hline GG 9 & $05 / 20$ & $1870 \mathrm{~g}$ & 7 & $<24$ hours & yes & Cesarean & RDS \\
\hline
\end{tabular}

RDS = Respiratory deficiency syndrome; *No available data.

resistance to ampicillin, cephalosporin (except cefoxitin), gentamicin and amikacin, with combinations of resistance to chloramphenicol, tetracycline and trimethoprim-sulfametoxazole. According to FRENCH et al. (1996), these strains of Klebsiella sp. do not respond to an empiric treatment with gentamicin or amikacin. LIVRELLI et al. (1996), emphasized that these bacterial strains are pathogens which cause infections, mainly on immuno-defficient patients.
$36 \%$ of Methicillin-resistant S. aureus (MRSA) were found. This result matches the results of other places in Brazil and other countries (LEVY et al., 1991; PANLILIO et al., 1992; VOSS et al., 1994; DURMAZ et al., 1997; SADER et al., 1999).

Despite of the relatively recent use of imipenem and ciprofloxacin in hospital, we observed a considerable level of resistance to gram 


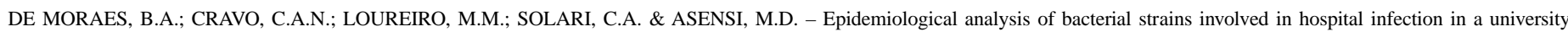
hospital from Brazil. Rev. Inst. Med. trop. S. Paulo, 42(4): 201-207, 2000.

negatives. STRUELENS et al. (1993) verified that $40 \%$ of $A$. baumannii strains are resistant to the latter antimicrobial in Brussels.

The nosocomial outbreak caused by Salmonella serovar Infantis was the first one in the literature. It showed the potential virulence of a plasmid of high molecular weight, and the multirresistance of this serovar, similar to that of serovars Typhimurium and Agona in pathogenicity, virulence and potential to cause outbreaks of hospital infections.

Recent studies on salmonellosis show that Infantis and Agona serovars have been isolated in stools and blood of children in hospitals in Rio de Janeiro, with a significant prevalence of Typhimurium serovar (ASENSI, SOLARI \& HOFER, 1994; ASENSI \& HOFER, 1994). This $S$. Infantis outbreak probably resulted from the vulnerability of the neonates due to their severe primary processes which favored the infection of the bacterium. Among the risk factors (Table 6) were observed prematurity and respiratory problems at birth. Besides, all of the newborns were in a neonatal pathologic nursery, submitted to invasive procedures.

Another interesting aspect was the presence of the higher molecular weight plasmid $(98 \mathrm{Md})$, which was probably involved with codification of virulence genes in Salmonella sp. The presence of a 60Md plasmid of $S$. Typhimurium increases virulence in mouse models as compared with plasmid free or plasmid cured strains (JONES et al., 1982; JONES \& OSBORNE, 1991). For some years, various publications have illustrated the role of plasmids as virulence related factors in various serovars of Salmonella. Chromosomal DNA is an important factor in expression of virulence, especially in the capacity of strains to survive and multiply in reticuloendothelial system cells. Nevertheless, the virulence of Salmonella strains is linked to a combination of chromosomal and plasmid DNA, the last one related to adhesion and invasion of $\mathrm{HeLa}$ cells and mouse infection (JONES et al., 1982; REXACH et al., 1994). In 1985, HELMUTH et al. characterized several virulence-associated plasmids in different Salmonella serovars.

The Committee for Hospital Infection Control used the results of this study to control new cases, optimize the use of antimicrobial in the hospital, implement its policies to reduce excess hospital stay and costs of medical care.

\section{RESUMO}

\section{Análise epidemiológica de cepas bacterianas envolvidas em infecção hospitalar em um Hospital Universitário no Brasil}

As infecções hospitalares representam um aumento na morbidade e mortalidade de pacientes internados, com significativo aumento no custo de internação hospitalar. Teve-se como objetivo fazer uma análise epidemiológica de casos de infecção hospitalar ocorridos num Hospital Universitário na cidade do Rio de Janeiro. Assim, foram analisadas 238 cepas isoladas a partir de 14 espécimens clínicos diferentes oriundos de 166 pacientes internados no período de 08 de 1995 a 07 de 1997. A idade média dos pacientes foi de 33,4 anos, 72,9\% faziam uso de antimicrobiano antes de apresentar a cultura positiva, as patologias de risco mais comuns foram: Cirurgia (19,3\%), HIV ou AIDS positivo $(18,1 \%)$ e Patologia Pulmonar (16,9\%). Foram identificadas 24 espécies bacterianas distintas, com predominância de $S$. aureus $(21 \%)$ e $P$. aeruginosa (18,5\%). Foram detectados 36\% de MRSA (Methicilin
Resistant $S$. aureus). Os Gram negativos apresentaram altos níveis de resistência para aminoglicosídeos e cefalosporinas. Foi detectado um surto de diarréia em berçário patológico, provocado pela Salmonella sorovar Infantis, com altos níveis de resistência para antimicrobianos e um plasmídio de alto peso molecular (98Mda), codificador do fator R.

\section{REFERENCES}

1.AL-ORAINEY, I.O.; AL-NASSER, M.N.; SAEED, E.S. \& CHOWDHURY, M.N.H. Nosocomial bacteraemia in a teaching hospital in Saudi Arabia. J. Hosp. Infect., 14: 201-207,1989.

2.ASENSI, M.D \& HOFER, E. - Serovars and multiple drug resistant Salmonella sp. isolated from children in Rio de Janeiro-Brazil. Rev. Microbiol. (S. Paulo), 25: 149-153, 1994.

3.ASENSI, M.D; SOLARI, C.A. \& HOFER, E. - A Salmonella agona outbreak in a pediatric hospital in the city of Rio de Janeiro-Brazil. Mem. Inst. Oswaldo Cruz, 89: 1-4, 1994

4.AYLIFFE, G.A.J. - The progressive intercontinental spread of methicillin-resistant Staphylococcus aureus. Clin. infect. Dis., 24 (suppl. 1): S74-S79, 1997.

5.BAIRD, G.D.; MANNING, E.J. \& JONES, P.W. - Evidence for related virulence sequences in plasmids of Salmonella dublin and Salmonella typhimurium. J. gen. Microbiol., 131: $1815-1823,1985$.

6.BALOWS, A.; HAUSLER JR., W.J.; HERRMANN, K.L.; ISENBERG, H.D. \& SHADOMY, H.J. - Manual of clinical microbiology. 5. ed. Washington, American Society for Microbiology, 1991.

7.BERGOGNE-BÉRÉZIN, E. - Les infections nosocomiales: nouveaux agents, incidence, prévention. Presse méd., 24: 89-97, 1995.

8.BIRNBOIM, H.C. \& DOLY, J. - A rapid alkaline extraction procedure for screening recombinant plasmid DNA. Nucleic Acids Res., 7: 1513-1523, 1979.

9.COTTON, M.F.; BERKOWITZ, F.E.; BERKOWITZ, Z.; BECKER, P.J. \& HENEY, C. Nosocomial infections in black South African children. Pediat. infect. Dis. J., 8: 676-683, 1989.

10. DUNCAN, J.M.G.; VALENCIA, E.; CELIZ, M.S.E. et al. - Vigilância de la suceptibilidad in vitro de las bacterias intrahospitalarias. Bol. Speit., 3: 25-30, 1994.

11. DURMAZ, B.; DURMAZ, R. \& SAHIN, K. - Methicillin-resistance among Turkish isolates the Staphylococcus aureus strains from nosocomial and community infections and their resistance patterns using various antimicrobial agents. J. Hosp. Infect., 37: 325-329, 1997.

12. FRENCH, G.L.; SHANNON, K.P. \& SIMMONS, N. - Hospital outbreak of Klebsiella pneumoniae resistant to broad-spectrum cephalosporins and $\beta$-lactam- $\beta$-lactamase inhibitor combinations by hiperproduction of SHV-5 $\beta$-lactamase. J. clin. Microbiol., 34: 358-363, 1996.

13. HELMUTH, R.; STEPHAN, R.; BUNGE, C. et al. - Epidemiology of virulenceassociated plasmids and outer membrane protein patterns within seven common Salmonella serotypes. Infect. Immun., 48: 175-182, 1985.

14. JARVIS, W.R. - Epidemiology of nosocomial infections in pediatric patients. Pediat. infect. Dis. J., 6: 344-351, 1987.

15. JONES, C.S. \& OSBORNE, D.J. - Identification of contemporary plasmid virulence genes in ancestral isolates of Salmonella enteritidis and Salmonella typhimurium. FEMS Microbiol. Lett., 80: 7-12, 1991.

16. JONES, G.W.; RABERT, D.K.; SVINARICH, D.M. \& WHITFIELD, H.J. - Association of adhesive, invasive, and virulent phenotypes of Salmonella typhimurium with autonomous 60-Megadalton plasmids. Infect. Immun., 38: 476-486, 1982. 
17. KOELEMAN, J.G.M.; PARLEVLIET, G.A.; DIJKSHOORN, L.; SAVELKOUL, P.H.M \& VANDENBROUCKE-GRAULS, C.M.J.E. - Nosocomial outbreak of multiresistant Acinetobacter baumannii on a surgical ward: epidemiology and risk factors for acquisition. J. Hosp. Infect., 37: 113-123, 1997.

18. LEVY, C.E.; MONTELLI, A.C.; FURTADO, J.S. et al. - Resistência a drogas em cepas bacterianas de serviços hospitalares: Laboratório de referência do sistema COBA. Rev. Microbiol. (S. Paulo), 22: 21-27, 1991.

19. LIVRELLI, V.; CHAMPS, C.; MARTINO, P. et al. - Adhesive properties and antibiotic resistance of Klebsiella, Enterobacter and Serratia clinical isolates involved in nosocomial infections. J. clin. Microbiol., 34: 1963-1969, 1996.

20. MACRINA, F.L.; KOPECKO, D.J.; JONES, K.R.; MAYERS, D.J. \& McCOWAN, S.M - A multiple plasmid-containing Escherichia coli strain: convenient source of size reference plasmid molecules. Plasmid, 1: 417- 420, 1978.

21. MANRIQUE, E.I. \& GALVÃO, L.L. - Racionalização e controle de antimicrobianos. In: RODRIGUES, E.A C.; MENDONÇA, J.S. de; AMARANTE, J. et al. - Infecções hospitalares: prevenção e controle. São Paulo, Sarvier, 1996.

22. MINISTRY OF HEALTH - BRAZIL / Ministério da Saúde-Brasil.Vigilância Epidemiológica por Compontes - Original Title: National Nosocomial Infection Surveillance System (NNISS-USA), 1994. 102 p.

23. MONNET, D.L.; BIDDLE, J.W.; EDWARDS, J.R. et al. - Evidence of interhospital transmission of extended-spectrum - $\beta$-Lactam-resistant Klebsiella pneumoniae in the United States, 1986 to 1993. Infect. Control Hosp. Epidem., 18: 492-498, 1997.

24. NATIONAL COMMITTEE FOR CLINICAL LABORATORY STANDARDS Performance standards for antimicrobial disk susceptibility tests. Approved Standard. NCCLS Publication M2-A5., 1993.

25. PANLILIO, A.L.; CULVER, D.G. \& GAYNES, R.P. - Methicillin-resistant Staphylococcus aureus in US hospitals, 1975-1991. Infect. Control Hosp. Epidem., 13: 582-586, 1992.

26. REXACH, L.; DILASSER, F. \& FACH, P. - Polymerase chain reaction for Salmonella virulence-associated plasmid genes detection: a new tool in Salmonella epidemiology. Epidem. Infect., 112: 33-43, 1994.
27. SADER, H.S.; SAMPAIO, J.L.M.; ZOCCOLI, C. \& JONES, R.N. - Results of the 1997 SENTRY Antimicrobial Surveillance Program in three Brazilian medical centers. Braz. J. infect. Dis., 3: 63-79, 1999.

28. SAMBROOK, J.; FRITSCH, E.F. \& MANIATS, T. - Molecular cloning: a laboratory manual. 2. ed. New York, Cold Spring Harbor Laboratory, 1989. p. 1-28.

29. SARTOR, C.; SAMBUC, R.; BIMAR, M.C.; GULIAN, C. \& DE MICCO, P. - Prevalence surveys of nosocomial infections using a ramdom sampling method in Marseille hospitals. J. Hosp. Infect., 29: 209-216, 1995.

30. SMITH, S.D. \& DOEBBELING, B.N. - Costs of nosocomial infections. Curr. Opin. infect. Dis., 9: 286-290, 1996.

31. STROUD, L.; SRIVASTAVA, P.; CULVER, D. et al. - Nosocomial infection in HIVinfected patients: preliminary results from a multicenter surveillance system (19891995). Infect. Control Hosp. Epidem., 18: 479-485, 1997.

32. STRUELENS, M.J.; CARLIER, E.; MAES, N. et al. - Nosocomial colonization and infection with multiresistant Acinetobacter baumannii outbreak delineation using DNA macrorestriction analysis and PCR-fingerprinting. J. Hosp. Infect., 25: 15-32, 1993

33. THRELFALL, E.J.; ROWE, B.; FERGUSON, J.L. \& WARD, L.R. - Characterization of plasmids conferring resistance to gentamicin and apramycin in strains of Salmonella typhimurium phage type 204c isolated in Britain. J. Hyg. (Lond.), 97: 419-426, 1986.

34. VOSS, A.; MILATOVIC, D.; WALLRAUCH-SCHWARZ, C.; ROSDALL, V.T. \& BRAVENEY, I. - Methicillin-resistant Staphylococcus aureus in Europe. Europ. J. clin. Microbiol. infect. Dis., 13: 50-55, 1994.

35. WENZEL, R.P. - Epidemiology of hospital-acquired infection . In: BALLOWS, A., ed. Manual of clinical microbiology. 5. ed. Washington, American Society for Microbiology, 1994. p. 147-150.

Received: 15 September 1999

Accepted: 15 May 2000 